Бранислав Остојић

\title{
РАЗВОЈ КЊИЖЕВНОГ ЈЕЗИКА У ЦРНОЈ ГОРИ И ВУКОВА ЈЕЗИЧКА РЕФОРМА
}

0. Намјера ми је да овим прилогом представим проблематику развоја стандардног језика у Црној Гори у историјској перспективи његове стандардизације, посебно за вријеме Вука и његове реформе, па затим да прикажем и пријем Вукове реформе у Црној Гори кроз фазу његове стандардизације у другој половини 19. в. с посебним освртом на језик штампе.

Полазну основу у овим разматрањима чини општа књижевнојезичка ситуација у Црној Гори која је претходила Вуку и која је условила безрезервно прихватање Вукове језичке реформе.

\section{II}

1. Вуково реформаторско доба у Црној Гори, као и у другим областима српскохрватског говорног подручја, наметнуло је проблем модернизације културе и њеног језичког израза - књижевног језика. У тешкој борби за књижевни језик Вук свјесно носи велики терет на плећима. Али, он није ниједног тренутка, чак ни онда када му је живот био у опасности, помишљао на одступницу. Његова борба за реформу књижевног језика, за реформу графије и ортографије и за фонетски принцип писања уздрмали су сву Војводину и Србију.

Нешто друкчије су та питања постављена, примана и разрешавана у Црној Гори. Горостасна фигура Петра II Петровића - Његоша уобличава и усмјерава свеукупна културна кретања. Стога су прилике у Црној Гори у сваком погледу, па и у култури, далеко једноставније и јасније него другдје. Сав тај посао текао је много мирније, без озбиљнијих проблема и трзавица, што је разумљиво и с обзиром на прилике које су претходиле 
Вукову времену и пратиле га на овом простору, о чему нам јасно говори кратак пресјек најважнијих момената с тим у вези.

1.1. У Црној Гори свеукупне прилике погодују Вуку. Језичка, као и културна ситуација уопште - била је много једноставнија. Ту није била потребна никаква супституција језичке основице стандарда. Прекида с предстандардним писањем у Црној Гори није било, стандардизација је била логичан и органски наставак предстандардних тенденција. Рускословенски, славеносерпски и народни елементи на овом терену нијесу били у међусобном сукобу око „превласти”. Црквенословенски је ту много раније почео да клизи ка пропасти, а народни језик да осваја просторе.

Владике су, посебно Петар Петровић Његош, увијек када им затреба, радо посезали за рускословенским, па и славеносерпским типом језика, служили се његовим изразима, мада они тамо (посебно овај последњи) нијесу били ухватили дубљег коријена. Његош је и пјесничком праксом и личним ставом према Вуковој акцији показивао склоност народном типу језика. То је, уосталом, карактерисало језик његова стрица Петра I који се с правом узима као претеча Вука Караџића на овим просторима. Његош је у потпуној сагласности са Вуковим принципима, показивао изванредан смисао и велику склоност према народном језику и народној пјесничкој традицији. Али, дубина и ширина његове поетске и филозофске инспирације нијесу могле остати у уским границама фолклорног израза. Пребравши и најскривеније кутке чудесне народне метафорике, Његош отвара сефове религиозних и општекултурних европских лексичких фондова и у свој језик уноси знатну грађу из тих сефова. Петар I je, иако његови радови нијесу штампани, својим дјелом на народном језику имао великог утицаја на Његоша. Њихов језик је у основи исти, само што је Његош у погодном тренутку показао како се народни говор може употребити у књижевности, без обзира на посезање за традицијом које се ни један ни други, а ни Вук, нијесу клонили.

1.2. Сви процеси у вези са језичком проблематиком у Црној Гори текли су спонтано и тихо. Вукова борба за књижевни језик, за реформу графије и правописа, као и догађаји у вези са усвајањем књижевног језика, нијесу имали озбиљнијих противника на црногорском говорном подручју, тако да се борба за реформу језика и писма и није вршила на том рејону. Књижевни језик и Вукова реформа прихваћени су у њој без отпора, као природан и завршан чин једног процеса који је већ ту имао у историјскојезичком континуитету дубоке „простонародне” коријене и плодно тло, што је имало, с друге стране, великог удјела и значаја за побједу Вукових начела на српскохрватском подручју уопште. 
2. Све је то у Црној Гори имало своје историјске предуслове који су својим особеностима погодовали испуњавању задатака Вукова времена. Те погодности су следеће:

2.1. Одржан је континуитет са средњовјековним (народним) типом језика, чему су на нарочит начин одговарале прилике које нијесу дозвољавале да се класе и поједини друштвени слојеви у Црној Гори међусобно диференцирају посебним повлашћеним и неповлашћеним положајима ни у друштвеном ни у културном животу. Према томе, писана књижевност која је у прошлости у друкчије постављеним условима била привилегована у Црној Гори била је блиска усменој књижевности народних маса тако да су се у поменутим околностима наведена два облика у основи јединствене књижевне дјелатности допуњавала. Зна се и то да генетски при појави писане књижевности, усмена традиција и народна књижевност чине њену полазну основу.

Црна Гора је у том погледу представљала специфичност. У њој до у скорашње доба, тако рећи, писана књижевност није имала ту судбину да се еманципује у засебну, вишу форму књижевног дјеловања, да се сасвим ослободи пресудног утицаја народне књижевности у којој је егзистирао народни језик - језик широких народних маса. Није такав језик егзистирао само у том корпусу, већ је и корпус осталих рукописних докумената писан на простом народном језику. За црногорско говорно подручје посебно је било специфично, а и данас је, његовање лијепе јавне ријечи, усмене, а дијелом и писано засвједочене, у чему значајно мјесто има таква ријеч Петра I Петровића.

2.2. У Боки је 17. и 18. в. испуњен књижевним радом, о чему нам говори, поред осталог, рукописни зборник народних пјесама које су се у народу пјевале у разним приликама а сачували их од заборава непознати, али ипак доста бројни бокељски записивачи. ${ }^{1}$ Има ту приљежног биљежења бугарштичких и гусларских народних пјесама. У црногорском приморју, посебно у Перасту и његовој околини, јављали су се, с времена на вријеме, пасионирани скупљачи народних умотворина; тако се нашао и један број изнемоглих - али вриједних и савјесних стараца да те пјесме забиљеже и сачувају од заборава. Има нешто од тога сачувано у рукописним биљешкама по Љутој, Доброти, Прчању и сусједним мјестима.

\footnotetext{
1 Павле Ивић, Српски народ и юегов језик, СКЗ, Београд, 1971, 148.
} 
Андрија Змајевић, родом из Пераста, иначе поријеклом из унутрашњости Црне Горе, препјевао је, као што је познато, Гундулићев $O$ сман у народне бугарштичке стихове. Из тога времена потиче и пасторални роман Љубдражића, који је вјешто саткан у стихове.

2.3. Народним језиком писане су и пјесме Владике Василија Петровића из средине 18. в. а такав је језик у Посланицама Петра I Петровића које су својеврсно књижевно остварење, па затим у његовим пјесмама и другим његовим књижевним остварењима.

2.4. И не само у наведеном корпусу који је литерарног карактера него и у другим корпусима. У писмима, на примјер, и преписци, тестаментима и исправама и другим документима у употреби је опет народни језик. ${ }^{2}$ Такве су и Паштровске исправе са црногорског приморја из 16. в., с главнином из 17. и 18. стољећа.

2.5. Много је више такве грађе сачувано на Цетињу. Данашњи архиви: цетињски, дубровачки, которски, задарски, а дјелимично и архив САНУ у Београду пуни су такве грађе која потиче из 16. в., а већина је тих докумената упућивана из Црне Горе у 17. и 18. в. дубровачкој и млетачкој властели; знатан дио ње је пристизао, на примјер, цетињском двору из унутрашњости Црне Горе и обратно. Сва су та документа писана опет народним језиком, у свима њима је оцртан локални говорни идиом. Њихов језик је, дакле, чисто народни и он је у оптицају у таквом медију од најстаријих времена, па је као такав посебно значајан за праћење континуитета у развоју књижевног језика.

3. „Проблем стандардизације на овом тлу с обзиром на однос према дијалекатској бази знатно је друкчији него у другим крајевима српског језичког подручја." Половину данашње Црне Горе прекрива најпрогресивнији дио штокавског дијалекта, говорна зона на чијим је основама изграђен новоштокавски фолклорни коине које је Вук у оба случаја - и као дијалекат и као књижевнојезичко остварење - узео у основицу савременог књижевног језика. ${ }^{3}$

Други дио данашње Црне Горе припада старијим штокавским говорима али се, и на том подручју, као и на оном првом, стварала народна књижевност, његовала лијепа усмена ријеч, која није знала за међе и границе.

${ }^{2}$ П. Ивић, Нав. дело, 157.

${ }^{3}$ М. Пешикан, Наш књижевни језик на сто година послије Вука, Београд, 1970, 89. 
Тако, на примјер, Петар I Петровић, Вуков претеча, који дијалекатски не припада истој говорној зони у Црној Гори, настојао је да као владар и митрополит црногорски и тај други дио Црне Горе веже за ондашњу Црну Гору. Са тамошњим се племенима и дописивао, намијенио им велики број посланица - једноставно тежио је да им се што више приближи. У томе је и успијевао. Свој израз је вјешто подешавао племену којему намјењује посланице. То је, уосталом, радио и када се обраћао племенима са подручја тадашњег црногорског приморја. Значи, он се поменутим племенима која су дијалекатски припадала новоштокавској говорној зони језички приближивао подешавајући свој израз зависно од племена којима је посланице намјењивао. Сасвим је онда разумљиво што у његовом књижевнојезичком изразу имамо особине новоштокавског дијалекта. Отуда језик његових посланица представља коине различитих црногорских говора са чијим је представницима читаво вријеме општио писмено или усмено. ${ }^{4}$

3.1. Дакле, црногорско је говорно подручје, поред свога домаћега дијалекта који је ушао у Вукову основицу књижевног језика, на цијелом свом простору, на једном и другом говорном типу његовало изванредан језик народних умотворина који је, такође, ушао у Вукову основицу књижевног језика, без обзира на то што није био увијек језик писане књижевности, али је наш књижевни језик преко тога и таквога језика добијао народну основицу. Уосталом, језик фолклорне књижевности ушао је у темеље српскохрватског књижевног језика. ${ }^{5}$ А то и због тога што је на обликовање говорног и писаног израза утицала популарна усмена и писана народна књижевност, као и омиљени умјетнички књижевни мотиви који су кружили по народу. ${ }^{6}$ Такав језик „фолклорне традиције” у Црној Гори у наведеним условима морао је показивати наддијалекатске особине, што значи да је био донекле граматички регулисан, семантички врло гибак и, са богатим синтаксичким односима народних говора, лексичким богатством и свима оним што језику даје стандардолошки карактер одговарао је углавном Вукову моделу књижевног језика, ${ }^{7}$ сасвим

4 Б. Остојић, Језик Петра I Петровића, ЦАНУ, Подгорица, 1976, 262-264.

5 Д. Брозовић, Стандардни језик, Загреб, 1970, 85-119; Х. Куна, Книжевна коине у релацији према предстандардним идиомима и стандардном језику, Књижевни језик, 1-2, Сарајево (1976), 9-20; Х. Куна, Језик босанскохериеговачке муслиманске народне поезије у односу према стандардном језику. - Књижевни језик VII, 3, 1978, (Сарајево) 5-299.

${ }^{6}$ И. Грицкат, Актуелни језички и текстолошки проблеми у старим српским ћирилским споменииима, Београд, 1972, 19.

7 Р. Бошковић, Одабрани члании и расправе, ЦАНУ, Титоград, 1978. 
је онда разумљиво што је Вук са својим принципима и реформом уопште у Црној Гори потпуно и безрезервно прихваћен.

3.2. Уколико је ријеч о умјетничкој литератури и језику у њој, може се слободно казати да је она до тада у Црној Гори била у скромним зачецима својим, али не и безначајна. Но сигурно је да се модел књижевног језика са фолклорном базом у Црној Гори почео изграђивати прије појаве Вука Караџића. Петар I Петровић, на примјер, вјешто се користио особеностима језика народне књижевности, и то, прије свега, језика поезије, којих није било у изразу свакодневне језичке комуникације, писане и говорне. Петар I је имао изграђен модел књижевног језика који се у основи не разликује од књижевног израза - Вукова и Његошева. Сва своја остварења, литерарног и оног другог карактера, посебно посланице, писао је језиком који је заиста представљао оригинални узорак наше прозе почетком прошлог вијека. ${ }^{8}$ У 19. в. Црна Гора има генијалног Његоша, па затим у другој половини 19. в. значајне писце као што су Стефан Митров Љубиша, Марко Миљанов а потом и низ врло корисних стваралаца у црногорској приповједачкој прози све до 1912. г. ${ }^{9}$ Љубиша се и поред настојања да остане у границама свог говорног идиома укључује својим језиком у вуковски модел књижевног језика последњих деценија прошлога вијека. Марко Миљанов се, међутим, језички чврсто ослонио на свој локални идиом чиме се несвјесно везао за Вуков став о књижевном језику у почетној фази његова рада „да сваки писац треба да пише својим дијалектом." У остварењима осталих приповједача среће се такође народни језик изразито фолклорно обојен.

3.3. Наведене погодности које смо ми овдје подијелили у основи на двије групе, имале су одлучујућу улогу у прихватању Вукове језичке реформе на црногорском простору. У свему овоме, наравно, није безначајно ни Вуково дробњачко поријекло, а ово се утемељило у Вуков и вуковски књижевни језик.

\section{V}

4. Његош се није јавно декларисао у вези са Вуковим идејама о реформи књижевног језика, реформи графије и ортографије, није се дакле, отворено изјашњавао ни као његов присталица, али ни као противник његових принципа - иако би се могло нешто слично очекивати, с обзиром

8 Б. Остојић, Језик Петра I Петровића, Титоград, 1976.

9 Чедо Вуковић, Црногорска приповједачка проза од Његоша до 1912, Титоград, 1973. 
на општепознати став Српске митрополије у Карловцима, ${ }^{10}$ па затим након изласка књиге Црна Гора и Бока Которска, гдје је Вук (како рече Миодраг Поповић) „сечивом науке ранио, оспорио Његошеву херојску визију Црне Горе” - морало је доћи до неспоразума. Они се „нису разумели. Морали су се интимно удаљити један од другога да се не би сасвим разишли."11

Па и поред свега тога у Његошево вријеме тридесетих година покреће се у Црној Гори годишњак „Грлица” који је уређивао Димитрије Милаковић. То је вријеме бурних превирања у српском књижевном језику. Иако у пет година његова излажења Вуково име није споменуто ниједанпут па иако није регистрован излазак Пословица на Цетињу 1836. г. - ипак је у њему наглашен интерес за Вукову реформу и показивано опредјељење за народни језик у књижевности.

Његов уредник Димитрије Милаковић је то показао и објављивањем једног фрагмента из драме Дика Црногорска С. Сарајлије да би показао ту приврженост народном језику преко овога дјела које се „чистотом српскога (готово црногорскога) језика одликује од свије његовије до сада печатаније дјела."12 У часопису се поштовао аутентичан израз сарадника, али је давана предност Вукову херцеговачком наречју о чему нам јасно говоре уредникове биљешке уз поједине текстове, као, на примјер, уз прилоге Петра I и уз десетерачке народне пјесме о појединим језичким особинама као мало познатим и регионално ограниченим. Као да је црногорски стандарднојезички израз почео да добија одређену стандарднојезичку надградњу.

Уредник алманаха написао је 1838. г. по Његошеву налогу Срnску граматику за ирногорску младеж, гдје је опредијељеност за источнохерцеговачки говор овдје у потпуности исказана. Општа правила су дата на основу стања у тим говорима уз поштовање неких специфичности црногорских говора које нијесу елиминисане из норме већ су сврстане у „особита правила”.

10 Р. Симић, Напомене о Вукову кюижевном језику, Југословенски семинар за стране слависте, 1979, бр. 30, 82.

11 Миодраг Поповић, Први сусрети Његоша и Вука. Стварање 9-10, Титоград, 1963, 154.

12 Дика Црногорска Симеоном Милутиновићем сочинена, Грлица, 1836, 123 (цит. по Р. Шуковићу, Примјена Вукове језичке и правописне норме у ирногорској итампи XIX в. Зборник Вук Стеф. Караџић, ЦАНУ 16, одјељ. умјет., $5,1988,38)$. 
Иначе, дјело је вишеструко значајно, поред осталог и за праћење развоја књижевног језика у Црној Гори као и по томе што оно чува ставове П. П. Његоша према Вуковој реформи. ${ }^{13}$

4.1. Кад се 60-их година 19. в. покреће годишњак „Орлић”, Вукова језичка реформа је у многоме и нормативно била довршена, а Вукова побједа није више била спорна. У Црној Гори је званично и декларативно била прихваћена реформа правописа у настави цетињске основне школе (1863). У овом часопису се рефлектују сва језичка струјања тих година у Црној Гори и шире, тако да он постаје најсигурнији извор за историју развитка књижевног језика у Црној Гори.

У годишњаку се прихватају норме стандардног језика у којему се још увијек укрштају Вукови реформски ставови са језиком средине, посебно оних језичких црта које су привлачиле и 30-их година часопис „Грлицу” и Димитрија Милаковића писца прве граматике у Црној Гори. Часопис је уствари вјерна копија књижевнојезичких прилика у администрацији црногорског сената и цјелокупног тадашњег црногорског државног апарата, школске администрације, документације и писане ријечи у Црној Гори уопште.

Иако књижевни језик у Црној Гори 60-их година карактерише постепено ишчезавање локалних језичких црта, као маргиналних у језичком понашању резервисаних за сфере интимне комуникације, ипак је још увијек дјелимично присутно одступање од Вукове језичке норме. Неке особине црногорских говора показују тенденцију да уђу у стандардне оквире. Према њима се испољава толерантан однос. Поштовао се аутентичан израз сарадника, што је посебно наглашено код црквеног великодостојника и европски за оно вријеме образованог интелектуалца Нићифора Дучића, Даничићева ђака, приређивача и сарадника „Орлића”. Он, на примјер, употребљава наставак -ах у ген. множ., облике дијалекатског јотовања које је Вук напустио 1839. г., облике тврде промјене замјеничко-придјевске деклинације, док код главног уредника и већине сарадника тога нема.

У употреби су оба писма; у примјени је етимолошки правопис уз незнатне примјене фонетског правописа. Иначе, ово вријеме у Црној Гори карактерише „грчевита” борба против Вукова фонетског правописа, а „Орлић” ће остати забиљежен у историји српскога језика у Црној Гори као последња књига штампана старим правописом.

4.2. Питање норме српскога језика покренуто на Цетињу 60-их година присутно је у 70-им годинама 19. в. На линији Нићифора Дучића

${ }^{13}$ Р. Шуковић, Нав. дело, 39. 
био је тих година и Лазар Томановић, један од уредника црногорских публикација, а у том правцу најдаље је отишао Ђуро Шпадијер, цетињски учитељ који је поменуте црногорске језичке посебности кодификовао као нормативне у Српској граматици за III и IV р. осн. школе (1900). Па и поред тога 70-их година 19. в. црногорску писану ријеч, посебно први црногорски лист „Црногорац” и први књижевни часопис „Црногорка”, карактерише тежња у примјени Вукове језичке норме, а већ 80-их година примјећује се велики напредак у примјени Вук-Даничићеве језичке норме. Многа колебања која су била актуелна у првим фазама стандардизације у часопису 30-их година па дјелимично и оних 60-их већ су сада превазиђена.

У последњој деценији 19. в. може се с правом рећи наступа и период диференцијације стилова нашег књижевног језика и он је уствари тек тада, како рече проф. Бошковић, пред својом стабилизацијом и нормализовањем - пред својим формирањем. ${ }^{14}$

Све мање је одступања од утврђене норме, примјењује се фонетски правопис, из језика су отклоњене фонетско-морфолошке особености „домаћег произношенија", примјењује се Вуково правило ијекавског наречја, израз је увијек лексички чист, а у прилозима хрватских писаца очуван је аутентичан израз, док су на другој страни доношени текстови на екавском изговору. ${ }^{15}$

5. Иначе, у Црној Гори се у другој половини 19. в. поклања изузетна пажња лексици народних говора, односно народним говорима уопште. Врши се допуна Вукова Рјечника из 1852. г. Вуков Рјечник се допуњава ријечима које се, како аутори ових прилога наводе, употребљавају са великом фреквенцијом и особина су српског књижевног језика. Допуњава се Вуков Рјечник и ријечима које су такође у живој народној употреби, али их не узимају као особину књижевног језика - остављају их као лексичке јединице дијалекатског карактера.

Ова два примјера нам говоре како су аутори језичких прилога у црногорским часописима осјећали потребу за нормирањем лексике те уједно вршили и прве покушаје у том погледу.

У неким прилозима аутори проучавају Вуков Рјечник са семантичке стране. И не само да се наведена питања анализирају у вези са прикупљањем и сређивањем лексичке грађе већ се у неким чланцима говори и о методологији рада на прикупљању и сређивању лексичког „блага нашега."

14 Р. Бошковић, Одабрани чланци и расправе, ЦАНУ, Титоград, 1978.

15 Р. Шуковић, Црногорски алманаси и календари (1835-1914), Цетиње, 1980, 75. 
Знатна пажња се поклањала и његовању културе говора и начину борбе за чистоћу народног језика. У тим прилозима се увијек, као и у онима које је написао С. Матавуљ, подстичу књижевни и културни кругови да његују народни језик у књижевности, да се боре против утицаја страних ријечи које кваре и удаљавају језик од народнога. Матавуљ је, на примјер, приредио списак ријечи којима нема мјеста у стандардном српском језику са захтјевом да се на његово мјесто врате народне ријечи. Критички се осврће на неке поступке који угрожавају речник народног језика, али се не супротстављају ни укључивању тог истог језика у међународну цивилизацију. Попут Вука ни аутори у оваквим прилозима нијесу против потпуног истребљења туђих ријечи из нашег књижевног језика. ${ }^{16}$

Чланци о језику у црногорским публикацијама из Вуковог и поствуковског периода пружају драгоцјене податке и бацају нешто друкчију свјетлост на улогу и значај не само штампе него уопште писаца, културних и јавних радника, научника и сл. за развој књижевног језика.

Процеси активне и свјесне језичке стандардизације врше се управо појавом првих часописа у Црној Гори. За ово вријеме урађено је у Црној Гори доста и у области проучавања нашега језика. Прикупљана је лексика и објављене су збирке ријечи, покушано је са израдом митолошког речника - управо започето је његово објављивање у часопису „Нова Зета”, рађени су језички приручници, граматике и правописни савјетници - све оно што тражи нормирање неког језика.

Бранислав Остоич

РАЗВИТИЕ ЛИТЕРАТУРНОГО ЯЗЫКА В ЧЕРНОГОРИИ И ЯЗЫКОВАЯ РЕФОРМА ВУКА КАРАДЖИЧА

Резюме

В данной работе автором рассматривается развитие литературного языка в Черногории. Исходным пунктом является тамошняя питературно-языковая ситуация, предшествовавшая Вуку Караджичу и обусловившая безоговорочное принятие его языковой реформы. Стандардизация языка в Черногории явилась логичным и органическим продолжением достандартных тенденций. На первых этапах своего развития стандартный

${ }^{16}$ Б. Остојић, Вук и књижевни језик у Црној Гори, Никшић, 1989, 35. 
язык не удовлетворяет всем требованиям стандартности. На следующем этапе постепенно решаются вопросы о норме. Последнее десятилетие XIX века является периодом дифференциации стилей; стандартный язык тогда находится перед своей стабилизацией и нормализацией - перед своим формированием. 